・生物编目・

$$
\begin{aligned}
& \text { 金沙江上游干旱河谷植被 } \\
& \text { 李云琴 }{ }^{1} \text { 杜 } \text { 2* }^{*} \text { 汪 健 }{ }^{2} \text { 李瑞年 }{ }^{2} \text { 刘 洋 }{ }^{2} \\
& 1 \text { (云南省林业科学院, 昆明 650201) } \\
& 2 \text { (西南林业大学林学院, 昆明 650224) }
\end{aligned}
$$

\begin{abstract}
摘要: 为了解金沙江上游奔子栏到羊拉约 $130 \mathrm{~km}$ 河段范围内干旱河谷的植被特征, 作者采用样带与典型样方相结 合的方法, 对该河段进行了植物群落调查。结果显示: (1)研究区域记录到野生维管植物 51 科 95 属111种(含种下等 级)，其中，茨类植物 4 科 4 属 6 种; 无裸子植物; 被子植物中双子叶植物 40 科 71 属 84 种; 单子叶植物 7 科 20 属 21 种。 (2)群落物种以草本为主, 达 67 种, 占总物种数的 $60.36 \%$; 生活型以地面芽植物为主, 占总物种数的 $32.43 \%$, 矮高 位芽次之, 占 $27.93 \%$; 叶型以微型和小型叶为主, 微型叶有 30 种, 占统计总数 $(50$ 种)的 $60 \%$, 小型叶有 11 种, 占总 数的 $22 \%$ 。(3)用双向指示种分析方法可将 93 个样方分为 5 个群系。分布最广、物种丰富度最高的是小叶荆 + 小叶 野丁香(Form. Vitex microphylla + Leptodermis pilosa var. microphylla)群系。(4)根据对该河谷区域的气候特点、干 旱程度、植被特征(植株矮化、叶片小、植物毛被发达、植株具刺、部分植物有吸湿反应性特征等)的分析，综合 植物群落的外貌、结构、物种构成和植物形态，可以确认金沙江上游干旱河谷植被具有亚热带荒漠植被类型的 特征。
\end{abstract}

关键词: 金沙江上游; 干旱河谷; 亚热带荒漠植被; 生活型；群落外貌

\title{
Desert vegetation in dry valleys of the upstream of Jinsha River
}

\author{
Yunqin $\mathrm{Li}^{1}$, Fan $\mathrm{Du}^{2 *}$, Jian Wang ${ }^{2}$, Ruinian $\mathrm{Li}^{2}$, Yang $\mathrm{Liu}^{2}$ \\ 1 Yunnan Academy of Forestry, Kunming 650201 \\ 2 Faculty of Forestry, Southwest Forestry University, Kunming 650224
}

\begin{abstract}
In order to understand the vegetation characteristics of dry valleys in the upstream of Jinsha River, a field survey was conducted by using transect and sampling surveys with 93 plots from September to October of 2011. Results showed that: (1) There were 111 vascular plant species belonging to 95 genera in 51 families, including 6 ferns belonging to 4 genera in 4 families, and 84 species of dicotyledon belonging to 71 genera in 40 families, 21 species of monocotyledon belonging to 20 genera in 7 families. (2) Five main life forms: Nanophanerophyte, Hemicryptophyte, Chamaephyte, Therophyte and Geophyte, can be recognized, of which Hemicryptophyte was the most dominant, occupying 32.43\% and Nanophanerophyte accounted for $27.93 \%$ of the total. The dominant leaf size belonged to nanophyll and microphyll, accounted for $60 \%$ and $22 \%$, respectively. (3) 93 sampling plots can be classified into 5 community types using a two-way Indicators Species Analysis. The species richness of herbs were higher than shrubs, and the richness of the Formation Vitex microphylla +Leptodermis pilosa var. microphylla was the greatest and also distributed most widely. (4) The vegetation in the dry valleys of the upstream of Jinsha River can be regarded as subtropical desert.
\end{abstract}

Key words: upstream of Jinsha River; dry valley; desert vegetation; life form; community physiognomy

金沙江上游是我国西南地区最为典型的干旱 河谷区之一，由于早年不通公路，该区域一直是植
被调查的薄弱区域。《中国植被》中曾指出四川、 云南、贵州一带受焚风作用的干旱河谷, 为非地带

收稿日期: 2015-09-11; 接受日期: 2016-04-26

基金项目: 云南省重点学科“野生动植物保护与利用”(XKZ200904)

* 通讯作者 Author for correspondence. E-mail: kmdufan@163.com 
性的河谷性荒漠植被类型的出现创造了局部的生 境(吴征镒, 1980), 但其资料并未覆盖金沙江上游干 旱河谷区域。《四川植被》中将干旱河谷植被分为 干旱灌丛(北部)和稀疏灌木草丛(南部) (四川植被协 作组, 1980)。1987年出版的《云南植被》(吴征镒等, 1987)中将河谷旱生植被作为稀疏灌木草丛的 1 个类 型，也没有关注本区域干旱河谷植被。云南大学金 振洲教授团队于 20 世纪 80 年代开始研究云南的干 热干暖河谷植被(金振洲等, 1987, 1994; 金振洲, 1999; 金振洲和欧晓昆，2000)。但迄今为止，对金 沙江河谷的研究均未涉及奔子栏以上极度干旱的 区域。

本文根据实地调查，力求揭示金沙江上游干旱 河谷的植被特征, 以期为下一步更加全面地研究横 断山三江并流区植被提供数据参考。

\section{1 研究区概况}

金沙江上游滇西北德钦县奔子栏(交界河汇口) 到羊拉河段, 地处 $28^{\circ} 11^{\prime}-28^{\circ} 58^{\prime} \mathrm{N}, 9^{\circ} 01^{\prime}-99^{\circ} 12^{\prime} \mathrm{E}$, 位于滇、川、藏3省交界区，长约 $130 \mathrm{~km}$ 。研究区海 拔2,000-3,020 m, 河谷深陷, 谷深多在 $2,000 \mathrm{~m}$ 以 上，谷壁陡峭，坡度总体大于 $50^{\circ}$, 河谷呈“V”字型。 奔子栏(海拔 $2,020 \mathrm{~m}$ ) 最高气温 $37^{\circ} \mathrm{C}$, 最低气温 $-4^{\circ} \mathrm{C}$ (骆银辉等, 2008), 降水量 $286 \mathrm{~mm}$ 。其附近的上桥头 水文站年平均降水量仅 $203 \mathrm{~mm}$, 年干燥度3.5-5.0 (张荣祖, 1992)。同样是附近的得荣县城(海拔2,422 $\mathrm{m})$ 年平均降水量 $347.1 \mathrm{~mm}$, 年蒸发量 $2,368.8 \mathrm{~mm}$, 蒸发量是降水量的6倍以上(黄云辉, 2013)。

金沙江奔子栏-交界河汇口段为中国 $29^{\circ} \mathrm{N}$ 以南 降水量最少的地方, 是名副其实的“干谷” (黄英和 李自顺, 2006)。本研究区奔子栏(交界河汇口)以上 河谷至今未设水文及气候观测点, 缺少相关气象数 据。但比奔子栏镇所在地更干旱，降水更稀少。实 地访问得知, 研究区雨季短暂, 降雨集中在7-9月 且降雨量极少，其他季节基本不下雨，极为干燥。

\section{2 方法}

\section{1 样方调查}

从奔子栏镇附近上游的交界河汇口沿奔子栏羊拉公路, 顺金沙江边逐渐向上游的德钦县羊拉方 向, 选择约 $130 \mathrm{~km}$ 长的河段。通过踏查, 选择6条垂 直典型样带, 样带间隔约 $20 \mathrm{~km}$, 海拔范围约2,000-
$3,000 \mathrm{~m}$, 在样带上共设置 100 个 $10 \mathrm{~m} \times 10 \mathrm{~m}$ 的样 方。相邻样方间的垂直高差约 $100 \mathrm{~m}$ 。于2011年9月 底至10月初，调查每个样方中植物的种类、高度、 盖度、株数、叶面积大小等; 并记录生境因子。选 择其中典型的 93 个样方作研究。

\section{2 数据分析}

由于样方中没有乔木成分, 故计算样方中灌木 的重要值, 作为确定植物群落类型的重要依据, 利 用双向指示种分析方法(two-way indicators species analysis，TWINSPAN) 进行群落的聚类(张金屯， 2004)。草本/灌木层重要值 $=($ 相对频度 + 相对盖 度 + 相对多度 $) / 3$ 。

采用 Raunkiaer 系统(曲仲湘等, 1983)划分生活 型和叶级谱。

选用物种丰富度测度群落内的物种多样性。

\section{3 结果}

\section{1 群落外貌}

研究区内植被的群落盖度介于 $3-25 \%$, 高度 3-200 cm，灌木层盖度为 $2-20 \%$, 草本层盖度为 $0.5-25 \%$ 。以抗旱能力较强、分布稀疏的超旱生灌 木、半灌木和小半灌木为主，几乎都是落叶种类， 有刺的种类也较多; 分枝低矮, 丛状; 叶小、革质, 毛被发达, 外貌灰绿色。

\section{2 群落物种组成}

样方中记录到维管植物 51 科 95 属 111 种(含种下 等级) (附录1), 包括锁类植物4科4属6种，被子植物 中双子叶植物 40 科 71 属 84 种, 单子叶植物 7 科 20 属 21 种。其中，草本 67 种，占总种数的 $60.36 \%$; 灌木 44 种, 占总种数的 $39.64 \%$ 。每个样方中物种数为 $5-24$ 种, 平均12.8种。

优势科为禾本科(13属14种)和菊科(9属14种), 占总科数的 $3.92 \%$ 。优势属为蒿属 (Artemisia，4种) 和卷柏属(Selaginella, 3种); 含2种的属有9属, 占总 属数的 $9.47 \%$, 如鹅线藤属 (Cynanchum)、雀梅藤属 (Sageretia)、石莲属(Sinocrassula)等; 含1种的属有 84 属，占总属数的 $88.42 \%$ ，如羊蹄甲属(Bauhinia)、 香茶菜属(Rabdosia)、醉鱼草属(Buddleja)、槐属 (Sophora) 等。

\section{3 群落生活型谱及叶型}

\subsection{1 生活型谱}

植物生活型以地面芽种类最多，达36种，占总 
种数的 $32.43 \%$ (图 1), 如环根芹 (Cyclorhiza waltonii)、芸香草(Cymbopogon distans)、康定翠雀花 (Delphinium tatsienense) 等。高位芽植物均为矮高位 芽类型, 计 31 种, 占 $27.93 \%$, 如架棚(Ceratostigma minus)、小叶灰毛莸(Caryopteris forrestii var. minor)、小叶荆(Vitex microphylla) 等, 主要是耐旱落叶 灌木。一年生草本 17 种, 占 $15.32 \%$, 如直立点地梅 (Androsace erecta)、杂配轴莍(Axyris hybrida)、德钦 画眉草(Eragrostis deqinensis)等。地上芽植物 14 种, 占 $12.61 \%$, 主要有云南蒿(Artemisia yunnanensis)、 小叶鹅线藤 (Cynanchum anthonyanum)、灰岩木蓝 (Indigofera calcicola) 等。地下芽植物 13 种, 占 $11.71 \%$, 如卷叶黄精(Polygonatum cirrhifolium)、曲 序南星 (Arisaema tortuosum)、独尾草 (Eremurus chinensis $)$ 等。

\subsection{2 叶型}

研究区植物的叶片较小, 以硬叶、毛叶、狭叶、 刺叶、肉质叶为特征。硬叶植物如德钦画眉草, 毛 叶植物如芸香草、茅叶荩草(Arthraxon prionodes)、 短穗冠芒草(Enneapogon brachystachyus) 等, 狭叶 植物如白草(Pennisetum flaccidum), 刺叶植物如多 刺天门冬(Asparagus myriacanthus), 肉质叶植物如 长葶石莲(Sinocrassula ambigua)、德钦景天(Sedum wangii)等。这些特征是对该区极度干旱气候的 适应。

根据Raunkiaer创建的叶型分类系统，将金沙江 干热河谷的植物叶级进行分类。由于气候干早, 大 部分草本植物叶片卷缩、枯黄, 因而只对灌木层植 物及部分草本植物进行了叶型分类, 共 50 种。其中 以微型叶和小型叶为主, 微型叶有 30 种, 占统计总 数的 $60 \%$, 小型叶有 11 种, 占总数的 $22 \%$ (图2)。从 叶型的分布可以看出当地生境的干和热, 适应干旱 生境的小型叶植物能够生长良好。

\subsection{3 有刺植物}

有刺植物共 12 种，占总物种数的 $10.81 \%$ 。其中, 有刺草本是猪毛菜 (Salsola collina)、刺花莲子草 (Alternanthera pungens)、千针苋(Acroglochin persicarioides), 灌木有单刺仙人掌(Opuntia monacanta)、峨嵋蓄薇(Rosa omeiensis)、对节刺(Sagerretia pycnophylla)、白刺花(Sophora davidii)、西南 蓄薇(Rosa muirielae)、多刺天门冬、刺铁线莲 (Clematis delavayi var. spinescens)、凹叶雀梅藤

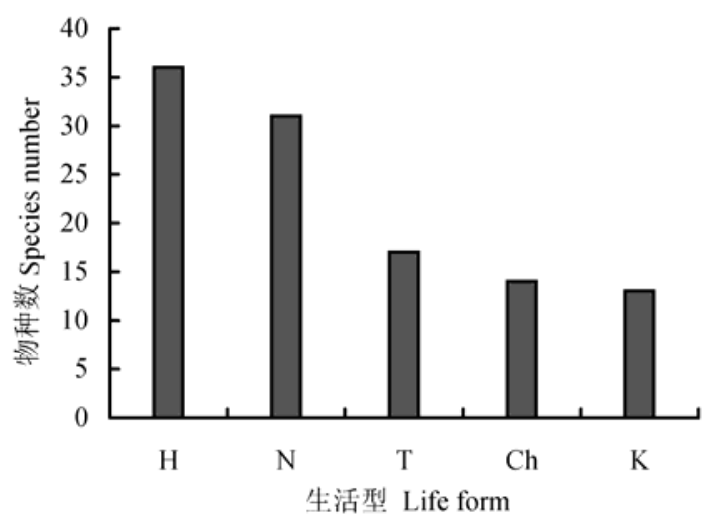

图1 金沙江上游干旱河谷植物生活型统计。 H: 地面芽; N: 矮高位芽; $\mathrm{T}:$ 一年生; $\mathrm{Ch}$ : 地上芽; $\mathrm{K}$ : 地下芽。

Fig. 1 Plant life form in dry valleys of the upstream of Jinsha River. H, Hemicryptophyte; N, Nanophanerophyte; T, Therophyte; Ch, Chamaephyte; K, Geophyte.

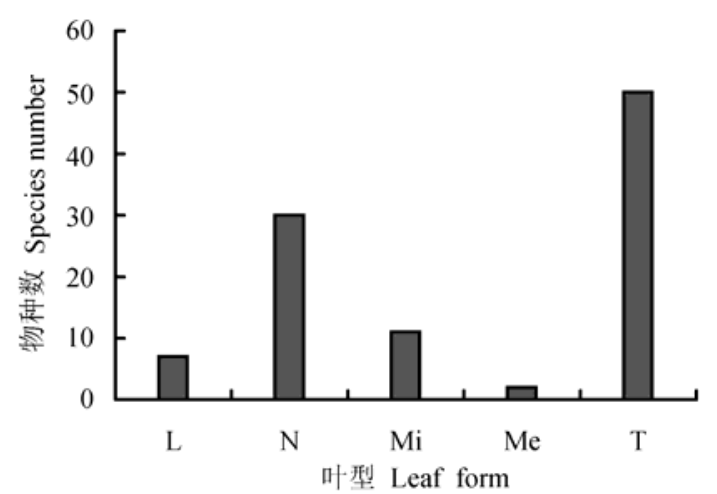

图2 金沙江上游干旱河谷植物叶型分类。 $\mathrm{L}$ : 鳞型叶; $\mathrm{N}$ : 微 型叶; Mi: 小型叶; Me: 中型叶; $\mathrm{T}$ : 总计。

Fig. 2 Plant leaf form in dry valleys of the upstream of Jinsha River. L, Leptophyll; N, Nanophyll; Mi, Microphyll; Me, Mesophyll; T, Total.

(Sageretia horrida)、淡黄鼠李(Rhamnus flavescens) 等。频度最大的是白刺花, 出现于 43 个样方, 频度 达 $46.24 \%$ 。有刺植物比例高同样是干旱植被的显著 特征。

\section{4 群落类型划分}

应用双向指示种分析(TWINSPAN)方法, 将 93 个样方划分为 5 组, 对应于 5 个群系(表 1$)$ 。这一分类 结果与野外观察的群落实际情况相符, 表明采用 TWINSPAN方法进行植物群落划分是可行的。

\section{5 物种丰富度}

物种丰富度(图3, 附录2)最高的是小叶荆 + 小叶野丁香群系(Form. Vitex microphylla + Leptodermis pilosa var. microphylla $)(S=72)$, 最低的是小 
表1 金沙江上游干旱河谷植被型

Table 1 Vegetation types in dry valleys of the upstream of Jinsha River

\begin{tabular}{lll}
\hline 植被型 & 植被亚型 & 群系 Formation \\
Vegetation type & Vegetation subtype & \\
\hline 荒漠 & 干旱河谷荒漠 & 1. 小叶荆+小叶野丁香群系 Form. Vitex microphylla + Leptodermis pilosa var. microphylla \\
Desert & Dry valley vegetation & 2. 白刺花+小叶荆群系 Form. Sophora davidii + Vitex microphylla \\
& 3. 灰岩木蓝+胶粘香茶菜群系 Form. Indigofera calcicola + Rabdosia glutinosa \\
& 4. 小叶荆+小叶杭子梢群系 Form. Vitex microphylla + Campylotropis wilsonii \\
& 5. 小叶灰毛莸+胶粘香茶菜群系 Form. Caryopteris forrestii var. minor + Rabdosia glutinosa \\
\hline
\end{tabular}

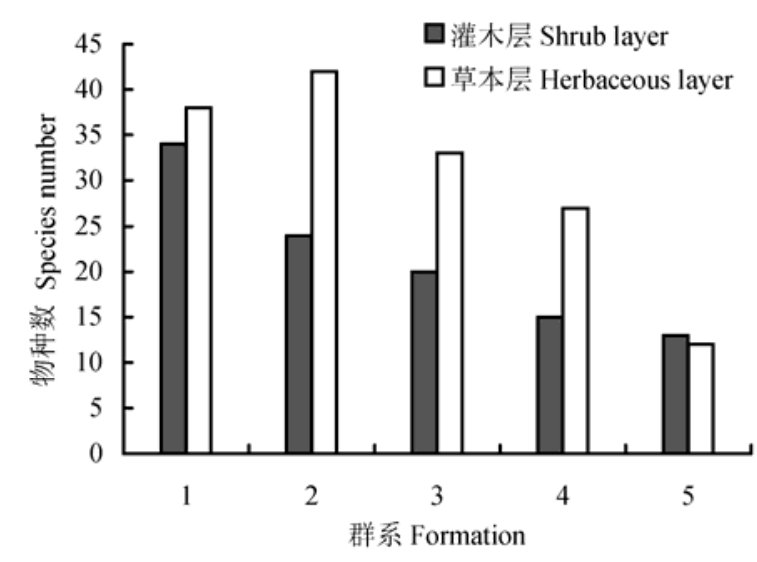

图3 金沙江上游干旱河谷荒漠植物群落物种丰富度。1: 小 叶荆+小叶野丁香群系; 2: 白刺花+小叶荆群系; 3: 灰岩木 蓝+胶粘香茶菜群系; 4: 小叶荆+小叶杭子梢群系; 5: 小叶 灰毛获+胶粘香茶菜群系

Fig. 3 The species richness of plant communities in dry valleys of the upstream of Jinsha River. 1, Form. Vitex microphylla + Leptodermis pilosa var. microphylla; 2, Form. Sophora davidii + Vitex microphylla; 3, Form. Indigofera calcicola + Rabdosia glutinosa; 4, Form. Vitex microphylla + Campylotropis wilsonii; 5, Form. Caryopteris forrestii var. minor + Rabdosia glutinosa

叶灰毛获 + 胶粘香茶菜群系(Form. Caryopteris forrestii var. minor + Rabdosia glutinosa $)(S=25)$ 。灌 木层的物种丰富度低于草本层, 较为明显的是白刺 花 + 小叶荆群系(Form. Sophora davidii + Vitex microphylla) 和灰岩木蓝 + 胶粘香茶菜群系(Form. Indigofera calcicola + Rabdosia glutinosa)。草本丰富 度远大于灌木, 说明群落生境严酷, 高蒸发、低降 水的干旱河谷更适合耐旱的草本植物生长。

\section{4 讨论}

内蒙古阿拉善高原荒漠是我国温带荒漠植被 的典型类型。何明珠等(2010)的研究结果表明, 在阿 拉善高原荒漠70种植物中，高位芽占 $35.7 \%$, 地上

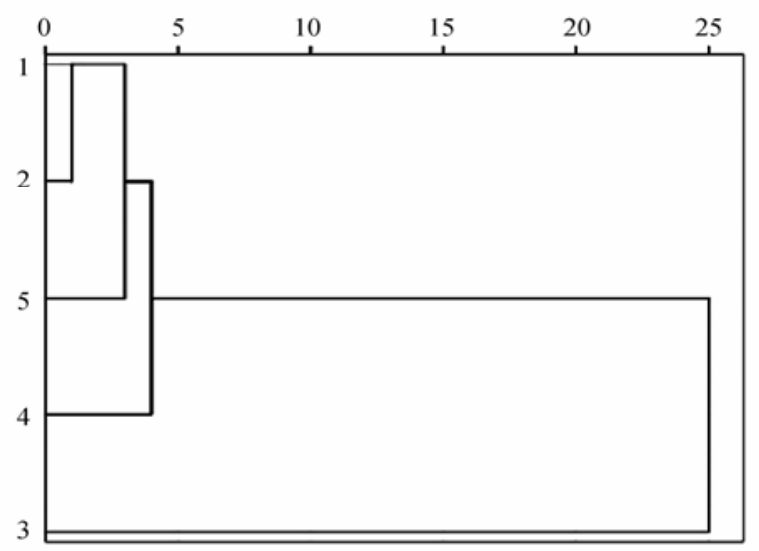

图4 相似地区的植物生活型聚类分析结果。1: 金沙江上游; 2: 阿拉善(何明珠等, 2010); 3: 金沙江中下游(欧晓昆和金振 洲, 1996); 4: 元江干热河谷(金振洲，1999)；5：怒江中游(庄 翠珍等, 2011)

Fig. 4 The cluster analysis of plant community life form in five areas. 1, Upstream the Jinsha River; 2, Alxa Plateau (He et al, 2010); 3, Middle and lower Jinsha River (Ou \& Jin, 1996); 4, Dry-hot valley of Yuanjiang River (Jin, 1999); 5, Middle reaches of Nujiang River (Zhuang et al, 2011)

芽占 $17.2 \%$ ，地面芽占 $32.9 \% ， 一$ 年生草本占 $7.1 \%$ 。 欧晓昆和金振洲(1996)对金沙江中下游河谷灌从植 被的研究结果表明, 在 1,004 种植物中, 高位芽占 $39.6 \%$ ，地上芽占 $29.4 \%$ ，地面芽占 $9 \%$ ，地下芽占 $7.3 \%$, 一年生草本占 $22.8 \%$; 金振洲(1999)对元江干 热河谷半萨王纳植被的 300 种植物的研究结果表明, 高位芽占 $36.0 \%$ ，地上芽占 $12.0 \%$ ，地面芽占 $26.7 \%$, 地下芽占 $2.7 \%$, 一年生植物占 $22.6 \%$ 。庄翠珍等 (2011)对怒江中游西藏境内的干旱河谷荒漠植被的 85 种植物的研究结果表明, 高位芽占 $41.2 \%$, 地上 芽占 $8.2 \%$ ，地面芽占 $40 \%$ ，一年生植物占 $10.6 \%$ 。5 个区域植物生活型聚类分析结果表明(图4), 本研究 区干旱河谷植被的生活型谱与阿拉善及怒江中游 的荒漠植被更接近，即高位芽和地面芽是主要的生 
活型, 这是荒漠植被生活型谱的重要特征(何明珠 等, 2010)。

本研究区域干旱、少雨、气温高, 有较长早季, 蒸发量极大; 生境坡度大、石砾多、土壤基质为典 型的干燥剥蚀岩漠类型, 缺乏土壤、保水困难, 更 加剧了气候的干旱效应。植被盖度很低, 研究区的 干旱河谷植被存在于河谷底部垂直范围500-800 m 的区域。所调查的 93 个样方的群落盖度仅 $3-15 \%$ 。 在河谷底部相对湿润的沟等处植被盖度可达到 $30 \%$ 左右, 但是这样的沟等生境在研究区只占极少数, 大面积生境极为干燥, 形成广泛的干旱、稀疏、低 矮的旱生植被(附录3), 植株矮化、叶片小型化、植 物毛被发达、植株多具刺、部分植物有吸湿反应特 征(张荣祖, 1992)。

植被外貌及生活型谱与我国西北地区的灌木 型温带荒漠植被较接近, 即均为由超旱生、中温、 叶退化或特化的落叶半灌木、灌木组成的稀疏植被 (吴征镒，1980; 何明珠等，2010); 与怒江中游西藏 境内的干旱河谷荒漠植被也较一致(庄翠珍等, 2011): 植被稀疏矮小, 盖度极低, 地表大面积裸露, 整体外貌呈灰绿色。

本文所研究的植被具有非地带性、局部性以及 变化性的特点。该区域植物种类组成、群落结构与 外貌以及生态条件等方面均与滇西北反映大气候 的地带性植被类型——寒温性针叶林完全不同, 它 是在河谷深陷、焚风效应显著的干旱河谷气候条件 下形成的特殊植被类型。此类特殊植被仅存在于河 谷底部垂直高程 500-800 $\mathrm{m}$ 的区域。随两岸山地海 拔上升, 生境逐渐湿润, 其植被逐渐被盖度更大的 鼠李(Rhamnus davurica)灌丛、高山松(Pinus densata) 林、云杉(Picea asperata) 和冷杉(Abies fabri)林 等类型所取代。

本研究在金沙江上游的奔子栏到羊拉河段做 了干旱河谷的植被调查, 调查资料是对前人的研究 进行的补充。根据金沙江上游干旱河谷的气候和环 境特点、植被特征等方面的分析, 并结合 《中国植 被》对荒漠的划分，金沙江上游干旱河谷的植被类 型可能是滇西北地区特定生境下产生的非地带性 的干旱河谷型荒漠植被, 有待进一步研究。

\section{参考文献}

He MZ, Zhang ZS, Li XJ, Jia RL, Zhang JG, Zheng JG (2010)
Environmental effects on distribution and composition of desert vegetations in Alxa Plateau. I. Environmental effects on the distribution patterns of vegetation in Alxa Plateau. Journal of Desert Research, 30, 46-56. (in Chinese with English abstract) [何明珠, 张志山, 李小军, 贾荣亮, 张景 光, 郑敬刚 (2010) 阿拉善高原荒漠植被组成分布特征 及其环境解释. I. 典型荒漠植被分布格局的环境解释. 中 国沙漠, 30, 46-56.]

Huang Y, Li ZS (2006) Rainfall change in lognitudinal valley areas of northwestern Yunnan. Journal of China Hydrology, 26(6), 68-70. (in Chinese) [黄英, 李自顺 (2006) 低纬地 区的“干谷”: 滇西北纵向岭谷区雨量之变化分析. 水文, 26(6), 68-70.]

Huang YH (2013) Analysis on the characteristics and causes of drought in Derong. China Science \& Technology, (17), 224. (in Chinese with English abstract) [黄云辉 (2013) 得荣干 旱特点及成因浅析. 中国科技纵横, (17), 224.]

Jin ZZ, Ou XK, Zhou Y (1987) The general situation of natural vegetation in dry-hot river valley of Yuanmou, Yunnan Province. Acta Phytoecologica et Geobotanica Sinica, 11, 308-317. (in Chinese) [金振洲, 欧晓昆, 周跃 (1987) 云 南元谋干热河谷植被概况. 植物生态学与地植物学学报, 11, 308-317.]

Jin ZZ, Ou XK, Ou PD, Chen J (1994) A preliminary study on the floristic characteristics of seed plants in the dry-hot river valley of Jinshajiang. Acta Botanica Yunnanica, 16, 1-16. (in Chinese with English abstract) [金振洲, 欧晓昆, 区普 定，陈洁 (1994) 金沙江干热河谷种子植物区系特征的 初探. 云南植物研究, 16, 1-16.]

Jin ZZ (1999) A phytosociological study on the semi-savanna vegetation in the dry-hot valleys of Yuanjiang River, Yunnan. Guihaia, 19, 289-302. (in Chinese with English abstract) [金振洲 (1999) 云南元江干热河谷半萨王纳植被 的植物群落学研究. 广西植物, 19, 289-302.]

Jin ZZ, Ou XK (2000) Yuanjiang, Nujiang, Jinshajiang, Lancangjiang Vegetation of Dry-Hot Valley. Yunnan University Press, Yunnan Science \& Technology Press, Kunming. (in Chinese) [金振洲, 欧晓昆 (2000) 元江、怒江、金沙江、 澜沧江干热河谷植被. 云南大学出版社, 云南科技出版 社, 昆明.]

Luo YH, Zhou DY, Zhu RH, He Y (2008) Primary study on environment of geology and bionomics in the area of world natural inheritance: the three rivers juxtaposition. Journal of Geological Hazards and Environment Preservation, 19(2), 94-97. (in Chinese with English abstract) [骆银辉, 周道银, 朱荣华，和勇 (2008) 世界自然遗产: “三江”并流区地质 生态环境特征及其成因初探. 地质灾害与环境保护, 19(2), 94-97.]

Ou XK, Jin ZZ (1996) A preliminary study on the flora and ecological diversity in Jinsha River dry-hot valley. Journal of Wuhan Botanical Research, 14, 318-322. (in Chinese with English abstract) [欧晓昆, 金振洲 (1996) 金沙江干 热河谷植物区系和生态多样性的初步研究. 武汉植物学 
研究, 14, 318-322.]

Qu ZX, Wu YS, Wang HX, Jiang HQ, Tang TG (1983) Plant Ecology, 2nd edn. Higher Education Press, Beijing. (in Chinese) [曲仲湘, 吴玉树, 王焕校, 姜汉侨, 唐廷贵 (1983) 植物生态学(第二版). 高等教育出版社, 北京.]

Sichuan Vegetation Group (1980) Sichuan Vegetation. Sichuan People's Publishing House, Chengdu. (in Chinese) [四川植 被协作组 (1980) 四川植被. 四川人民出版社, 成都.]

Wu ZY (1980) Vegetation of China. Science Press, Beijing. (in Chinese) [吴征镒 (1980) 中国植被. 科学出版社, 北京.]

Wu ZY, Zhu YC, Jiang HQ (1987) Yunnan Vegetation. Science Press, Beijing. (in Chinese) [吴征镒, 朱彦丞, 江 汉侨 (1987) 云南植被. 科学出版社, 北京.]

Zhang JT (2004) Quantitative Ecology. Science Press, Beijing. (in Chinese) [张金屯 (2004) 数量生态学. 科学出版社,
北京.]

Zhang RZ (1992) Scientific Investigation Series in Hengduan Mountains of Tibetan Plateau: Dry Valleys in the Hengduan Mountains. Science Press, Beijing. (in Chinese) [张荣祖 (1992) 青藏高原横断山区科学考察从书: 横断山区干旱 河谷. 科学出版社, 北京.]

Zhuang CZ, Du F, Liu N, Zhang H, Chen Y, Du XL (2011) Vegetative characteristics in the dry valley of the middle reaches of Nujiang River in Tibet, China. Plant Diversity and Resources, 33, 433-442. (in Chinese with English abstract) [庄翠珍, 杜凡, 刘宁, 张辉, 陈勇, 杜小浪 (2011) 怒江中游西藏境内干旱河谷荒漠植被特征. 植物分类与 资源学报, 33, 433-442.]

(责任编委: 沈泽昊 责任编辑: 间文杰)

\section{附录 Supplementary Material}

\section{附录1 金沙江上游干旱河谷植物物种统计表}

Appendix 1 Plant species checklist in dry valleys of the upstream of Jinsha River http://www.biodiversity-science.net/fileup/PDF/2015238-1.pdf

附录2 金沙江上游干旱河谷 5 个群系植物物种组成

Appendix 2 Species composition of 5 plant formations in dry valleys of the upstream of Jinsha River http://www.biodiversity-science.net/fileup/PDF/2015238-2.pdf

\section{附录3 金沙江上游干旱河谷区部分生境及群系照片}

Appendix 3 The photos of habitat and plant formations in dry valleys of the upstream of Jinsha River http://www.biodiversity-science.net/fileup/PDF/2015238-3.pdf 
附录1 金沙江上游干旱河谷植物物种统计表

Appendix 1 Plant species checklist in dry valleys of the upstream of Jinsha River

\begin{tabular}{|c|c|c|c|c|c|c|}
\hline $\begin{array}{c}\text { 序号 } \\
\text { Number }\end{array}$ & $\begin{array}{c}\text { 中文名 } \\
\text { Chinese name }\end{array}$ & $\begin{array}{c}\text { 拉丁名 } \\
\text { Latin name }\end{array}$ & $\begin{array}{l}\text { 生长型 } \\
\text { Growth } \\
\text { form }\end{array}$ & $\begin{array}{c}\text { 出现样 } \\
\text { 方数 } \\
\text { Number }\end{array}$ & $\begin{array}{c}\text { 频度 } \\
\text { Frequency } \\
(\%)\end{array}$ & $\begin{array}{l}\text { 生活型 } \\
\text { Life form }\end{array}$ \\
\hline 1 & 小叶荆 & Vitex microphylla & 灌木 Shrub & 66 & 70.97 & $\mathrm{~N}$ \\
\hline 2 & 折叶白前 & Cynanchum forrestii var. conduplicatum & 灌木 Shrub & 60 & 64.52 & $\mathrm{Ch}$ \\
\hline 3 & 灰岩木蓝 & Indigofera calcicola & 灌木 Shrub & 62 & 66.67 & Ch \\
\hline 4 & 德钦画眉草 & Eragrostis deqinensis & 草本 Herb & 62 & 66.67 & $\mathrm{~T}$ \\
\hline 5 & 白刺花 & Sophora davidii & 灌木 Shrub & 43 & 46.24 & $\mathrm{~N}$ \\
\hline 6 & 小叶野丁香 & Leptodermis pilosa var. microphylla & 灌木 Shrub & 45 & 48.39 & $\mathrm{~N}$ \\
\hline 7 & 小叶灰毛获 & Caryopteris forrestii var. minor & 灌木 Shrub & 46 & 49.46 & $\mathrm{~N}$ \\
\hline 8 & 小鞍叶羊蹄甲 & Bauhinia brachycarpa var. microphylla & 灌木 Shrub & 51 & 54.84 & $\mathrm{~N}$ \\
\hline 9 & 短穗冠芒草 & Enneapogon brachystachyus & 草本 Herb & 42 & 45.16 & $\mathrm{H}$ \\
\hline 10 & 垫状卷柏 & Selaginella pulvinata & 草本 Herb & 49 & 52.69 & $\mathrm{H}$ \\
\hline 11 & 粗毛狗娃花 & Heteropappus altaicus var. hirsutus & 草本 Herb & 48 & 51.61 & K \\
\hline 12 & 架棚 & Ceratostigma minus & 灌木 Shrub & 22 & 23.66 & $\mathrm{~N}$ \\
\hline 13 & 胶粘香茶菜 & Rabdosia glutinosa & 灌木 Shrub & 24 & 25.81 & $\mathrm{~N}$ \\
\hline 14 & 皱叶腺花醉鱼草 & Buddleja agathosma var. glandulifera & 灌木 Shrub & 29 & 31.18 & $\mathrm{~N}$ \\
\hline 15 & 四川草沙蚕 & Tripogon sichuanicus & 草本 Herb & 20 & 21.51 & $\mathrm{H}$ \\
\hline 16 & 白边卷柏 & Selaginella albocincta & 草本 Herb & 20 & 21.51 & $\mathrm{H}$ \\
\hline 17 & 芸香草 & Cymbopogon distans & 草本 Herb & 22 & 23.66 & $\mathrm{H}$ \\
\hline 18 & 茅叶荩草 & Arthraxon prionodes & 草本 Herb & 26 & 27.96 & $\mathrm{H}$ \\
\hline 19 & 小叶鹅线藤 & Cynanchum anthonyanum & 灌木 Shrub & 20 & 21.51 & Ch \\
\hline 20 & 怒江蒿 & Artemisia nujianensis & 灌木 Shrub & 36 & 38.71 & Ch \\
\hline 21 & 雪白粉背蕨 & Aleuritopteris niphobola & 草本 Herb & 21 & 22.58 & K \\
\hline 22 & 疏穗小野养麦 & Fagopyrum leptopodum var. grossii & 草本 Herb & 20 & 21.51 & $\mathrm{~T}$ \\
\hline 23 & 复芒菊 & Formania mekongensis & 灌木 Shrub & 1 & 1.08 & $\mathrm{~N}$ \\
\hline 24 & 小叶栒子 & Cotoneaster nitidus var. parvifolius & 灌木 Shrub & 2 & 2.15 & $\mathrm{~N}$ \\
\hline 25 & 川滇野丁香 & Leptodermis pilosa & 灌木 Shrub & 1 & 1.08 & $\mathrm{~N}$ \\
\hline 26 & 清香木 & Pistacia weinmannifolia & 灌木 Shrub & 1 & 1.08 & $\mathrm{~N}$ \\
\hline 27 & 西南蓄薇 & Rosa muirielae & 灌木 Shrub & 1 & 1.08 & $\mathrm{~N}$ \\
\hline 28 & 峨嵋蓄薇 & Rosa omeiensis & 灌木 Shrub & 1 & 1.08 & $\mathrm{~N}$ \\
\hline 29 & 陕西绣线菊 & Spiraea wilsonii & 灌木 Shrub & 1 & 1.08 & $\mathrm{~N}$ \\
\hline 30 & 尖齿蛇葡萄 & Ampelopsis acutidentata & 灌木 Shrub & 2 & 2.15 & $\mathrm{~N}$ \\
\hline 31 & 川康栒子 & Cotoneaster ambiguus & 灌木 Shrub & 2 & 2.15 & $\mathrm{~N}$ \\
\hline 32 & 迎春花 & Jasminum nudiflorum & 灌木 Shrub & 2 & 2.15 & $\mathrm{~N}$ \\
\hline 33 & 单刺仙人掌 & Opuntia monacanta & 灌木 Shrub & 2 & 2.15 & $\mathrm{~N}$ \\
\hline 34 & 沙针 & Osyris wightiana & 灌木 Shrub & 2 & 2.15 & $\mathrm{~N}$ \\
\hline 35 & 少花豆腐柴 & Premna oligantha & 灌木 Shrub & 2 & 2.15 & $\mathrm{~N}$ \\
\hline 36 & 淡黄鼠李 & Rhamnus flavescens & 灌木 Shrub & 2 & 2.15 & $\mathrm{~N}$ \\
\hline 37 & 凹叶雀梅藤 & Sageretia horrida & 灌木 Shrub & 2 & 2.15 & $\mathrm{~N}$ \\
\hline 38 & 云南土沉香 & Excoecaria acerifolia & 灌木 Shrub & 3 & 3.23 & $\mathrm{~N}$ \\
\hline 39 & 错枝榄仁 & Terminalia intricata & 灌木 Shrub & 3 & 3.23 & $\mathrm{~N}$ \\
\hline 40 & 对节刺 & Sagerretia pycnophylla & 灌木 Shrub & 4 & 4.30 & $\mathrm{~N}$ \\
\hline 41 & 革叶莪花 & Wikstroemia scytophylla & 灌木 Shrub & 4 & 4.30 & $\mathrm{~N}$ \\
\hline 42 & 华西小石积 & Osteomeles schwerinae & 灌木 Shrub & 12 & 12.90 & $\mathrm{~N}$ \\
\hline 43 & 刺铁线莲 & Clematis delavayi var. spinescens & 灌木 Shrub & 14 & 15.05 & $\mathrm{~N}$ \\
\hline 44 & 小叶杭子梢 & Campylotropis wilsonii & 灌木 Shrub & 16 & 17.20 & $\mathrm{~N}$ \\
\hline 45 & 雅致山蚂蝗 & Desmodium elegans & 灌木 Shrub & 17 & 18.28 & $\mathrm{~N}$ \\
\hline 46 & 竹叶柴胡 & Bupleurum marginatum & 草本 Herb & 1 & 1.08 & $\mathrm{H}$ \\
\hline 47 & 细柄草 & Capillipedium parviflorum & 草本 Herb & 1 & 1.08 & $\mathrm{H}$ \\
\hline 48 & 菊科一种 & Compositae sp. & 草本 Herb & 1 & 1.08 & $\mathrm{H}$ \\
\hline 49 & 中华野葵 & Malva verticillata var. chinensis & 草本 Herb & 1 & 1.08 & $\mathrm{H}$ \\
\hline 50 & 二歧马先蒿 & Pedicularis dichotoma & 草本 Herb & 1 & 1.08 & $\mathrm{H}$ \\
\hline 51 & 二叶舌唇兰 & Platanthera chlorantha & 草本 Herb & 1 & 1.08 & $\mathrm{H}$ \\
\hline
\end{tabular}




\begin{tabular}{|c|c|c|c|c|c|c|}
\hline $\begin{array}{c}\text { 序号 } \\
\text { Number }\end{array}$ & $\begin{array}{c}\text { 中文名 } \\
\text { Chinese name }\end{array}$ & $\begin{array}{c}\text { 拉丁名 } \\
\text { Latin name }\end{array}$ & $\begin{array}{l}\text { 生长型 } \\
\text { Growth } \\
\text { form }\end{array}$ & $\begin{array}{c}\text { 出现样 } \\
\text { 方数 } \\
\text { Number }\end{array}$ & $\begin{array}{c}\text { 频度 } \\
\text { Frequency } \\
\text { (\%) }\end{array}$ & $\begin{array}{l}\text { 生活型 } \\
\text { Life form }\end{array}$ \\
\hline 52 & 巴塘报春 & Primula bathangensis & 草本 Herb & 1 & 1.08 & $\mathrm{H}$ \\
\hline 53 & 戟叶酸模 & Rumex hastatus & 草本 Herb & 1 & 1.08 & $\mathrm{H}$ \\
\hline 54 & 长䔁石莲 & Sinocrassula ambigua & 草本 Herb & 1 & 1.08 & $\mathrm{H}$ \\
\hline 55 & 苼藜 & Tribulus terrester & 草本 Herb & 1 & 1.08 & $\mathrm{H}$ \\
\hline 56 & 中华粘腺果 & Commicarpus chinensis & 草本 Herb & 2 & 2.15 & $\mathrm{H}$ \\
\hline 57 & 环根芹 & Cyclorhiza waltonii & 草本 Herb & 2 & 2.15 & $\mathrm{H}$ \\
\hline 59 & 云南百部 & Stemona mairei & 草本 Herb & 2 & 2.15 & $\mathrm{H}$ \\
\hline 60 & 多花亚菊 & Ajania myriantha & 灌木 Shrub & 3 & 3.23 & $\mathrm{H}$ \\
\hline 61 & 马尔康糙果芹 & Trachyspermum triradiatum & 草本 Herb & 3 & 3.23 & $\mathrm{H}$ \\
\hline 62 & 康定翠雀花 & Delphinium tatsienense & 草本 Herb & 4 & 4.30 & $\mathrm{H}$ \\
\hline 63 & 矮龙葵 & Solanum nigrum var. humile & 草本 Herb & 4 & 4.30 & $\mathrm{H}$ \\
\hline 64 & 西南菅草 & Themeda hookeri & 草本 Herb & 4 & 4.30 & $\mathrm{H}$ \\
\hline 65 & 马唐属一种 & Digitaria sp. & 草本 Herb & 5 & 5.38 & $\mathrm{H}$ \\
\hline 66 & 纺锤根蝇子草 & Silene napuligera & 草本 Herb & 7 & 7.53 & $\mathrm{H}$ \\
\hline 67 & 白草 & Pennisetum flaccidum & 草本 Herb & 8 & 8.60 & $\mathrm{H}$ \\
\hline 68 & 岷江景天 & Sedum balfouri & 草本 Herb & 8 & 8.60 & $\mathrm{H}$ \\
\hline 69 & 黄细心 & Boerhavia diffusa & 草本 Herb & 9 & 9.68 & $\mathrm{H}$ \\
\hline 70 & 扭黄茅 & Heteropogon contortus & 草本 Herb & 9 & 9.68 & $\mathrm{H}$ \\
\hline 71 & 禾本科一种 & Poaceae sp. & 草本 Herb & 9 & 9.68 & $\mathrm{H}$ \\
\hline 72 & 石胆草 & Corallodiscus flabellatus & 草本 Herb & 10 & 10.75 & $\mathrm{H}$ \\
\hline 73 & 多枝滇紫草 & Onosma multiramosum & 草本 Herb & 11 & 11.83 & $\mathrm{H}$ \\
\hline 74 & 石莲 & Sinocrassula indica & 草本 Herb & 12 & 12.90 & $\mathrm{H}$ \\
\hline 75 & 细瘦卷柏 & Selaginella vardei & 草本 Herb & 15 & 16.13 & $\mathrm{H}$ \\
\hline 76 & 横断山铁马鞭 & Lespedeza fasciculiflora var. hengduanshanensis & 灌木 Shrub & 1 & 1.08 & $\mathrm{Ch}$ \\
\hline 77 & 两头毛 & Incarvillea arguta & 灌木 Shrub & 1 & 1.08 & $\mathrm{Ch}$ \\
\hline 78 & 胡枝子一种 & Lespedeza sp. & 灌木 Shrub & 1 & 1.08 & $\mathrm{Ch}$ \\
\hline 79 & 腺毛唐松草 & Thalictrum foetidum & 草本 Herb & 1 & 1.08 & $\mathrm{Ch}$ \\
\hline 80 & 云南蒿 & Artemisia yunnanensis & 灌木 Shrub & 2 & 2.15 & $\mathrm{Ch}$ \\
\hline 81 & 云南栉叶蒿 & Neopallasia yunnanensis & 草本 Herb & 2 & 2.15 & $\mathrm{Ch}$ \\
\hline 82 & 缺刻千里光 & Senecio scandens var. incisus & 草本 Herb & 3 & 3.23 & $\mathrm{Ch}$ \\
\hline 83 & 头花香薷 & Elsholtzia capituligera & 灌木 Shrub & 5 & 5.38 & $\mathrm{Ch}$ \\
\hline 84 & 灰苍蒿 & Artemisia roxburghiana & 灌木 Shrub & 6 & 6.45 & $\mathrm{Ch}$ \\
\hline 85 & 黄花蒿 & Artemisia annua & 灌木 Shrub & 13 & 13.98 & $\mathrm{Ch}$ \\
\hline 86 & 德钦景天 & Sedum wangii & 草本 Herb & 3 & 3.23 & $\mathrm{~K}$ \\
\hline 87 & 蜈蚣蓱 & Pteris vittata & 草本 Herb & 1 & 1.08 & $\mathrm{~K}$ \\
\hline 88 & 西南风铃草 & Campanula pallida & 草本 Herb & 2 & 2.15 & K \\
\hline 89 & 三角金毛裸蕨 & Paragymnopteris sargentii & 草本 Herb & 2 & 2.15 & K \\
\hline 90 & 卷叶黄精 & Polygonatum cirrhifolium & 草本 Herb & 2 & 2.15 & K \\
\hline 91 & 纤细五爪金龙 & Ipomoea cairca var. gracillima & 草本 Herb & 3 & 3.23 & $\mathrm{~K}$ \\
\hline 92 & 菟丝子 & Cuscuta chinensis & 草本 Herb & 4 & 4.30 & K \\
\hline 93 & 多刺天门冬 & Asparagus myriacanthus & 灌木 Shrub & 5 & 5.38 & K \\
\hline 94 & 曲序南星 & Arisaema tortuosum & 草本 Herb & 8 & 8.60 & K \\
\hline 95 & 真籽非 & Allium eusperma & 草本 Herb & 9 & 9.68 & K \\
\hline 96 & 独尾草 & Eremurus chinensis & 草本 Herb & 14 & 15.05 & K \\
\hline 97 & 狗尾草 & Setaria viridis & 草本 Herb & 9 & 9.68 & $\mathrm{~T}$ \\
\hline 98 & 千针苋 & Acroglochin persicarioides & 草本 Herb & 1 & 1.08 & $\mathrm{~T}$ \\
\hline 99 & 刺花莲子草 & Alternanthera pungens & 草本 Herb & 1 & 1.08 & $\mathrm{~T}$ \\
\hline 100 & 白花鬼针草 & Bidens pilosa var. radiata & 草本 Herb & 1 & 1.08 & $\mathrm{~T}$ \\
\hline 101 & 小白酒草 & Conyza canadensis & 草本 Herb & 1 & 1.08 & $\mathrm{~T}$ \\
\hline 102 & 酢浆草 & Oxalis corniculata & 草本 Herb & 1 & 1.08 & $\mathrm{~T}$ \\
\hline 103 & 猪毛菜 & Salsola collina & 草本 Herb & 1 & 1.08 & $\mathrm{~T}$ \\
\hline 104 & 川西獐牙菜 & Swertia mussotii & 草本 Herb & 1 & 1.08 & $\mathrm{~T}$ \\
\hline 105 & 風子草 & Tragus berteronianus & 草本 Herb & 1 & 1.08 & $\mathrm{~T}$ \\
\hline
\end{tabular}




\begin{tabular}{|c|c|c|c|c|c|c|}
\hline $\begin{array}{c}\text { 序号 } \\
\text { Number }\end{array}$ & $\begin{array}{c}\text { 中文名 } \\
\text { Chinese name }\end{array}$ & $\begin{array}{c}\text { 拉丁名 } \\
\text { Latin name }\end{array}$ & $\begin{array}{l}\text { 生长型 } \\
\text { Growth } \\
\text { form }\end{array}$ & $\begin{array}{c}\text { 出现样 } \\
\text { 方数 } \\
\text { Number }\end{array}$ & $\begin{array}{c}\text { 频度 } \\
\text { Frequency } \\
\text { (\%) }\end{array}$ & $\begin{array}{l}\text { 生活型 } \\
\text { Life form }\end{array}$ \\
\hline 106 & 细裂叶松蒿 & Phtheirospermum tenuisectum & 草本 Herb & 2 & 2.15 & $\mathrm{~T}$ \\
\hline 107 & 虎尾草 & Chloris virgata & 草本 Herb & 3 & 3.23 & $\mathrm{~T}$ \\
\hline 108 & 腺梗狶莶 & Siegesbeckia pubescens & 草本 Herb & 3 & 3.23 & $\mathrm{~T}$ \\
\hline 109 & 杂配轴藜 & Axyris hybrida & 草本 Herb & 9 & 9.68 & $\mathrm{~T}$ \\
\hline 110 & 藜 & Chenopodium album & 草本 Herb & 12 & 12.90 & $\mathrm{~T}$ \\
\hline 111 & 直立点地梅 & Androsace erecta & 草本 Herb & 13 & 13.98 & $\mathrm{~T}$ \\
\hline
\end{tabular}

$\mathrm{H}$ : 地面芽; N: 矮高位芽; T: 一年生; Ch: 地上芽; K: 地下芽

H, Hemicryptophyte; N, Nanophanerophyte; T, Therophyte; Ch, Chamaephyte; K, Geophyte 
附录 2 金沙江上游干旱河谷 5 个群系植物物种组成

Appendix 2 Species composition of 5 plant formations in dry valleys of the upstream of Jinsha River

1 小叶荆+小叶野丁香群系 Form. Vitex microphylla+Leptodermis pilosa var. microphylla

\begin{tabular}{|c|c|c|c|c|c|c|c|}
\hline $\begin{array}{c}\text { 中文名 } \\
\text { Chinese name }\end{array}$ & 拉丁名 Latin name & $\begin{array}{c}\text { 生长型 } \\
\text { Growth } \\
\text { form }\end{array}$ & $\begin{array}{l}\text { 出现样方 } \\
\text { 数 Number }\end{array}$ & $\begin{array}{c}\text { 相对盖度 } \\
\text { Relative } \\
\text { cover }\end{array}$ & $\begin{array}{c}\text { 相对频度 } \\
\text { Relative } \\
\text { frequency }\end{array}$ & $\begin{array}{c}\text { 相对多度 } \\
\text { Relative } \\
\text { abundance }\end{array}$ & $\begin{array}{c}\text { 重要值 } \\
\text { Important } \\
\text { value }\end{array}$ \\
\hline 针瓣景天 & Sedum obtusipetalum & 草本 & 1 & 0.0007 & 0.0041 & 0.0002 & 0.0015 \\
\hline 矮龙葵 & Solanum nigrum var. humile & 草本 & 1 & 0.0007 & 0.0041 & 0.0006 & 0.0018 \\
\hline 白花鬼针草 & Bidens pilosa var. radiata & 草本 & 1 & 0.0007 & 0.0041 & 0.0003 & 0.0017 \\
\hline 虎尾草 & Chloris virgata & 草本 & 1 & 0.0007 & 0.0041 & 0.0008 & 0.0019 \\
\hline 马尔康糛果芹 & Trachyspermum triradiatum & 草本 & 1 & 0.0007 & 0.0041 & 0.0003 & 0.0017 \\
\hline 缺刻千里光 & Senecio scandens var. incisus & 草本 & 1 & 0.0007 & 0.0041 & 0.0002 & 0.0017 \\
\hline 多刺天门冬 & Asparagus myriacanthus & 草本 & 2 & 0.0008 & 0.0083 & 0.0008 & 0.0033 \\
\hline 曲序南星 & Arisaema tortuosum & 草本 & 2 & 0.0014 & 0.0083 & 0.0003 & 0.0033 \\
\hline 纤细五爪金龙 & Ipomoea cairca var. gracillima & 草本 & 2 & 0.0014 & 0.0083 & 0.0023 & 0.0040 \\
\hline 云南百部 & Stemona mairei & 草本 & 2 & 0.0014 & 0.0083 & 0.0022 & 0.0040 \\
\hline 云南栉叶蒿 & Neopallasia yunnanensis & 草本 & 2 & 0.0014 & 0.0083 & 0.0012 & 0.0036 \\
\hline 纺锤根蝇子草 & Silene napuligera & 草本 & 3 & 0.0021 & 0.0124 & 0.0026 & 0.0057 \\
\hline 真籽非 & Allium eusperma & 草本 & 3 & 0.0021 & 0.0124 & 0.0028 & 0.0058 \\
\hline 黄细心 & Boerhavia diffusa & 草本 & 5 & 0.0022 & 0.0207 & 0.0012 & 0.0081 \\
\hline 直茎点地梅 & Androsace erecta & 草本 & 5 & 0.0022 & 0.0207 & 0.0059 & 0.0096 \\
\hline 中华粘腺果 & Commicarpus chinensis & 草本 & 1 & 0.0035 & 0.0041 & 0.0012 & 0.0029 \\
\hline 独尾草 & Eremurus chinensis & 草本 & 5 & 0.0035 & 0.0207 & 0.0056 & 0.0100 \\
\hline 丛毛羊胡子草 & Eriophorum comosum & 草本 & 4 & 0.0042 & 0.0166 & 0.0056 & 0.0088 \\
\hline 藜 & Chenopodium album & 草本 & 3 & 0.0042 & 0.0124 & 0.0054 & 0.0073 \\
\hline 马唐属一种 & Digitaria sp. & 草本 & 2 & 0.0042 & 0.0083 & 0.0025 & 0.0050 \\
\hline 禾本科一种 & Poaceae sp. & 草本 & 3 & 0.0042 & 0.0124 & 0.0053 & 0.0073 \\
\hline 小野养麦 & Fagopyrum leptopodum & 草本 & 8 & 0.0046 & 0.0332 & 0.0084 & 0.0154 \\
\hline 多枝滇紫草 & Onosma multiramosum & 草本 & 7 & 0.0049 & 0.0290 & 0.0054 & 0.0131 \\
\hline 岷江景天 & Sedum balfouri & 草本 & 4 & 0.0055 & 0.0166 & 0.0071 & 0.0098 \\
\hline 杂配轴藜 & Axyris hybrida & 草本 & 3 & 0.0055 & 0.0124 & 0.0048 & 0.0076 \\
\hline 石胆草 & Corallodiscus flabellatus & 草本 & 6 & 0.0076 & 0.0249 & 0.0082 & 0.0136 \\
\hline 石莲 & Sinocrassula indica & 草本 & 8 & 0.0077 & 0.0332 & 0.0132 & 0.0180 \\
\hline 白草 & Pennisetum flaccidum & 草本 & 4 & 0.0091 & 0.0166 & 0.0053 & 0.0103 \\
\hline 扭黄茅 & Heteropogon contortus & 草本 & 6 & 0.0104 & 0.0249 & 0.0127 & 0.0160 \\
\hline 雪白粉背偋 & Aleuritopteris niphobola & 草本 & 11 & 0.0104 & 0.0456 & 0.0174 & 0.0245 \\
\hline 粗毛狗娃花 & Heteropappus altaicus var. hirsutus & 草本 & 16 & 0.0177 & 0.0664 & 0.0313 & 0.0385 \\
\hline 中华草沙蚕 & Tripogon chinensis & 草本 & 10 & 0.0194 & 0.0415 & 0.0620 & 0.0410 \\
\hline 茅叶荩草 & Arthraxon prionodes & 草本 & 13 & 0.0361 & 0.0539 & 0.0254 & 0.0385 \\
\hline 短穗冠芒草 & Enneapogon brachystachyus & 草本 & 11 & 0.0396 & 0.0456 & 0.0398 & 0.0417 \\
\hline 德钦画眉草 & Eragrostis deqinensis & 草本 & 22 & 0.0445 & 0.0913 & 0.0936 & 0.0765 \\
\hline 白边卷柏 & Selaginella albocincta & 草本 & 14 & 0.0560 & 0.0581 & 0.1178 & 0.0773 \\
\hline 细瘦卷柏 & Selaginella vardei & 草本 & 7 & 0.1107 & 0.0290 & 0.2852 & 0.1416 \\
\hline 芸香草 & Cymbopogon distans & 草本 & 13 & 0.1135 & 0.0539 & 0.0578 & 0.0751 \\
\hline 狗尾草 & Setaria viridis & 草本 & 3 & 0.1335 & 0.0124 & 0.0313 & 0.0591 \\
\hline 垫状卷柏 & Selaginella pulvinata & 草本 & 25 & 0.3211 & 0.1037 & 0.1260 & 0.1836 \\
\hline 淡黄鼠李 & Rhamnus flavescens & 灌木 & 1 & 0.0002 & 0.0034 & 0.0008 & 0.0015 \\
\hline 对节刺 & Sagerretia pycnophylla & 灌木 & 1 & 0.0002 & 0.0034 & 0.0004 & 0.0013 \\
\hline
\end{tabular}




\begin{tabular}{|c|c|c|c|c|c|c|c|}
\hline 革叶荛花 & Wikstroemia scytophylla & 灌木 & 1 & 0.0002 & 0.0034 & 0.0004 & 0.0013 \\
\hline 云南土沉香 & Excoecaria acerifolia & 灌木 & 1 & 0.0002 & 0.0034 & 0.0004 & 0.0013 \\
\hline 沙针 & Osyris wightiana & 灌木 & 1 & 0.0004 & 0.0034 & 0.0008 & 0.0015 \\
\hline 清香木 & Pistacia weinmannifolia & 灌木 & 1 & 0.0010 & 0.0034 & 0.0012 & 0.0019 \\
\hline 凹叶雀梅藤 & Sageretia horrida & 灌木 & 2 & 0.0014 & 0.0069 & 0.0020 & 0.0034 \\
\hline 云南蒿 & Artemisia yunnanensis & 灌木 & 2 & 0.0014 & 0.0069 & 0.0080 & 0.0054 \\
\hline 黄花蒿 & Artemisia аппиа & 灌木 & 5 & 0.0020 & 0.0172 & 0.0068 & 0.0087 \\
\hline 头花香薷 & Elsholtzia capituligera & 灌木 & 2 & 0.0022 & 0.0069 & 0.0048 & 0.0046 \\
\hline 小叶鹅线藤 & Cynanchum anthonyanum & 灌木 & 11 & 0.0024 & 0.0379 & 0.0096 & 0.0167 \\
\hline 多花亚菊 & Ajania myriantha & 灌木 & 2 & 0.0030 & 0.0069 & 0.0056 & 0.0052 \\
\hline 迎春花 & Jasminum nudiflorum & 灌木 & 2 & 0.0042 & 0.0069 & 0.0064 & 0.0058 \\
\hline 皱叶腺花醉鱼草 & Buddleja agathosma var. glandulifera & 灌木 & 8 & 0.0046 & 0.0276 & 0.0136 & 0.0153 \\
\hline 小叶杭子梢 & Campylotropis wilsonii & 灌木 & 6 & 0.0050 & 0.0207 & 0.0088 & 0.0115 \\
\hline 胶粘香茶菜 & Rabdosia glutinosa & 灌木 & 7 & 0.0071 & 0.0241 & 0.0157 & 0.0156 \\
\hline 折叶白前 & Cynanchum forrestii var. conduplicatum & 灌木 & 22 & 0.0097 & 0.0759 & 0.0357 & 0.0404 \\
\hline 西南仙人掌 & Eremurus chinensis & 灌木 & 1 & 0.0119 & 0.0034 & 0.0140 & 0.0098 \\
\hline 华西小石积 & Osteomeles schwerinae & 灌木 & 6 & 0.0163 & 0.0207 & 0.0124 & 0.0165 \\
\hline 尖齿蛇葡萄 & Ampelopsis acutidentata & 灌木 & 2 & 0.0218 & 0.0069 & 0.0036 & 0.0108 \\
\hline 雅致山蚂蝗 & Desmodium elegans & 灌木 & 9 & 0.0270 & 0.0310 & 0.0281 & 0.0287 \\
\hline 两头毛 & Incarvillea arguta & 灌木 & 1 & 0.0297 & 0.0034 & 0.0096 & 0.0143 \\
\hline 刺铁线莲 & Clematis delavayi var. spinescens & 灌木 & 10 & 0.0371 & 0.0345 & 0.0405 & 0.0374 \\
\hline 灰岩木蓝 & Indigofera calcicola & 灌木 & 23 & 0.0527 & 0.0793 & 0.1168 & 0.0829 \\
\hline 少花豆腐柴 & Premna oligantha & 灌木 & 2 & 0.0535 & 0.0069 & 0.0261 & 0.0288 \\
\hline 白刺花 & Sophora davidii & 灌木 & 8 & 0.0551 & 0.0276 & 0.0429 & 0.0419 \\
\hline 小叶灰毛莸 & Caryopteris forrestii var. minor & 灌木 & 24 & 0.0563 & 0.0828 & 0.0911 & 0.0767 \\
\hline 怒江蒿 & Artemisia nujianensis & 灌木 & 21 & 0.0579 & 0.0724 & 0.0811 & 0.0705 \\
\hline 小鞍叶羊蹄甲 & Bauhinia brachycarpa var. microphylla & 灌木 & 22 & 0.0704 & 0.0759 & 0.0742 & 0.0735 \\
\hline 架棚 & Ceratostigma minus & 灌木 & 12 & 0.1292 & 0.0414 & 0.1100 & 0.0935 \\
\hline 小叶野丁香 & Leptodermis pilosa var. microphylla & 灌木 & 37 & 0.1483 & 0.1276 & 0.0891 & 0.1217 \\
\hline 小叶荆 & Vitex microphylla & 灌木 & 37 & 0.1877 & 0.1276 & 0.1392 & 0.1515 \\
\hline
\end{tabular}

2 白刺花+小叶荆群系 Form. Sophora davidii+Vitex microphylla

\begin{tabular}{|c|c|c|c|c|c|c|c|}
\hline 中文名 Chinese name & 拉丁名 Latin name & $\begin{array}{c}\text { 生长型 } \\
\text { Growth } \\
\text { form }\end{array}$ & $\begin{array}{c}\text { 出现样方数 } \\
\text { Number }\end{array}$ & $\begin{array}{c}\text { 相对盖度 } \\
\text { Relative } \\
\text { cover }\end{array}$ & $\begin{array}{c}\text { 相对频度 } \\
\text { Relative } \\
\text { frequency }\end{array}$ & $\begin{array}{c}\text { 相对多度 } \\
\text { Relative } \\
\text { abundance }\end{array}$ & $\begin{array}{c}\text { 重要值 } \\
\text { Importan } \\
\text { value }\end{array}$ \\
\hline 蜈蚣草 & Pteris vittata & 草本 & 1 & 0.0002 & 0.0057 & 0.0003 & 0.0021 \\
\hline 中华粘腺果 & Commicarpus chinensis & 草本 & 1 & 0.0002 & 0.0057 & 0.0003 & 0.0021 \\
\hline 千针苋 & Acroglochin persicarioides & 草本 & 1 & 0.0010 & 0.0057 & 0.0003 & 0.0023 \\
\hline 戟叶酸模 & Rumex hastatus & 草本 & 1 & 0.0020 & 0.0057 & 0.0006 & 0.0028 \\
\hline 刺花莲子草 & Alternanthera pungens & 草本 & 1 & 0.0020 & 0.0057 & 0.0009 & 0.0029 \\
\hline 䖝子草 & Tragus berteronianus & 草本 & 1 & 0.0020 & 0.0057 & 0.0015 & 0.0031 \\
\hline 小白酒草 & Conyza canadensis & 草本 & 1 & 0.0020 & 0.0057 & 0.0006 & 0.0028 \\
\hline 纤细五爪金龙 & Ipomoea cairca var. gracillima & 草本 & 1 & 0.0020 & 0.0057 & 0.0018 & 0.0032 \\
\hline 酢浆草 & Oxalis corniculata & 草本 & 1 & 0.0020 & 0.0057 & 0.0006 & 0.0028 \\
\hline 西南风铃草 & Campanula pallida & 草本 & 1 & 0.0020 & 0.0057 & 0.0009 & 0.0029 \\
\hline 石莲 & Sinocrassula indica & 草本 & 1 & 0.0020 & 0.0057 & 0.0012 & 0.0030 \\
\hline 钝瓣景天 & Sedum obtusipetalum & 草本 & 1 & 0.0020 & 0.0057 & 0.0015 & 0.0031 \\
\hline
\end{tabular}




\begin{tabular}{|c|c|c|c|c|c|c|c|}
\hline 独尾草 & Eremurus chinensis & 草本 & 1 & 0.0020 & 0.0057 & 0.0021 & 0.0033 \\
\hline 䠦藜 & Tribulus terrester & 草本 & 1 & 0.0020 & 0.0057 & 0.0009 & 0.0029 \\
\hline 菊科一种 & Compositae sp. & 草本 & 1 & 0.0020 & 0.0057 & 0.0006 & 0.0028 \\
\hline 石胆草 & Corallodiscus flabellatus & 草本 & 1 & 0.0020 & 0.0057 & 0.0018 & 0.0032 \\
\hline 矮龙葵 & Solanum nigrum var. humile & 草本 & 2 & 0.0021 & 0.0115 & 0.0015 & 0.0051 \\
\hline 虎尾草 & Chloris virgata & 草本 & 2 & 0.0039 & 0.0115 & 0.0027 & 0.0060 \\
\hline 多枝滇紫草 & Onosma multiramosum & 草本 & 2 & 0.0039 & 0.0115 & 0.0027 & 0.0060 \\
\hline 黄细心 & Boerhavia diffusa & 草本 & 1 & 0.0039 & 0.0057 & 0.0012 & 0.0036 \\
\hline 菟丝子 & Cuscuta chinensis & 草本 & 4 & 0.0043 & 0.0230 & 0.0018 & 0.0097 \\
\hline 腺梗稀荅 & Siegesbeckia pubescens & 草本 & 3 & 0.0059 & 0.0172 & 0.0030 & 0.0087 \\
\hline 马唐属一种 & Digitaria sp. & 草本 & 3 & 0.0059 & 0.0172 & 0.0037 & 0.0089 \\
\hline 直茎点地梅 & Androsace erecta & 草本 & 2 & 0.0059 & 0.0115 & 0.0091 & 0.0088 \\
\hline 长萝石莲 & Sinocrassula ambigua & 草本 & 1 & 0.0059 & 0.0057 & 0.0061 & 0.0059 \\
\hline 茅叶荩草 & Arthraxon prionodes & 草本 & 3 & 0.0078 & 0.0172 & 0.0049 & 0.0100 \\
\hline 曲序南星 & Arisaema tortuosum & 草本 & 6 & 0.0100 & 0.0345 & 0.0030 & 0.0158 \\
\hline 雪白粉背蒴 & Aleuritopteris niphobola & 草本 & 5 & 0.0119 & 0.0287 & 0.0107 & 0.0171 \\
\hline 中华草沙蚕 & Tripogon chinensis & 草本 & 3 & 0.0137 & 0.0172 & 0.0265 & 0.0191 \\
\hline 藜 & Chenopodium album & 草本 & 8 & 0.0176 & 0.0460 & 0.0186 & 0.0274 \\
\hline 杂配轴藜 & Axyris hybrida & 草本 & 6 & 0.0186 & 0.0345 & 0.0155 & 0.0229 \\
\hline 狗尾草 & Setaria viridis & 草本 & 5 & 0.0195 & 0.0287 & 0.0241 & 0.0241 \\
\hline 缺刻千里光 & Senecio scandens var. incisus & 草本 & 1 & 0.0195 & 0.0057 & 0.0018 & 0.0090 \\
\hline 小野养麦 & Fagopyrum leptopodum & 草本 & 10 & 0.0256 & 0.0575 & 0.0311 & 0.0381 \\
\hline 禾本科一种 & Poaceae sp. & 草本 & 4 & 0.0488 & 0.0230 & 0.0271 & 0.0330 \\
\hline 扭黄茅 & Heteropogon contortus & 草本 & 2 & 0.0508 & 0.0115 & 0.0393 & 0.0339 \\
\hline 粗毛狗娃花 & Heteropappus altaicus var. hirsutus & 草本 & 20 & 0.0557 & 0.1149 & 0.0732 & 0.0813 \\
\hline 芸香草 & Cymbopogon distans & 草本 & 4 & 0.0879 & 0.0230 & 0.0274 & 0.0461 \\
\hline 细瘦卷柏 & Selaginella vardei & 草本 & 3 & 0.0879 & 0.0172 & 0.2378 & 0.1143 \\
\hline 垫状卷柏 & Selaginella pulvinata & 草本 & 10 & 0.1191 & 0.0575 & 0.0549 & 0.0772 \\
\hline 德钦画眉草 & Eragrostis deqinensis & 草本 & 26 & 0.1240 & 0.1494 & 0.1988 & 0.1574 \\
\hline 短穗冠芒草 & Enneapogon brachystachyus & 草本 & 22 & 0.2133 & 0.1264 & 0.1570 & 0.1656 \\
\hline 灰苞蒿 & Artemisia roxburghiana & 灌木 & 1 & 0.0002 & 0.0046 & 0.0005 & 0.0018 \\
\hline 头花香蔏 & Elsholtzia capituligera & 灌木 & 1 & 0.0002 & 0.0046 & 0.0009 & 0.0019 \\
\hline 胡枝子一种 & Lespedeza sp. & 灌木 & 1 & 0.0002 & 0.0046 & 0.0009 & 0.0019 \\
\hline 胶粘香茶菜 & Rabdosia glutinosa & 灌木 & 1 & 0.0002 & 0.0046 & 0.0005 & 0.0018 \\
\hline 小叶杭子梢 & Campylotropis wilsonii & 灌木 & 2 & 0.0009 & 0.0092 & 0.0064 & 0.0055 \\
\hline 小叶鹅线藤 & Cynanchum anthonyanum & 灌木 & 3 & 0.0009 & 0.0138 & 0.0037 & 0.0061 \\
\hline 云南土沉香 & Excoecaria acerifolia & 灌木 & 1 & 0.0009 & 0.0046 & 0.0046 & 0.0034 \\
\hline 黄花蒿 & Artemisia аппиа & 灌木 & 6 & 0.0010 & 0.0276 & 0.0041 & 0.0109 \\
\hline 怒江蒿 & Artemisia nujianensis & 灌木 & 4 & 0.0023 & 0.0184 & 0.0051 & 0.0086 \\
\hline 对节刺 & Sagerretia pycnophylla & 灌木 & 2 & 0.0025 & 0.0092 & 0.0018 & 0.0045 \\
\hline 淡黄鼠李 & Rhamnus flavescens & 灌木 & 1 & 0.0045 & 0.0046 & 0.0009 & 0.0034 \\
\hline 小叶野丁香 & Leptodermis pilosa var. microphylla & 灌木 & 9 & 0.0061 & 0.0415 & 0.0138 & 0.0205 \\
\hline 雅致山蚂蝗 & Desmodium elegans & 灌木 & 6 & 0.0077 & 0.0276 & 0.0235 & 0.0196 \\
\hline 华西小石积 & Osteomeles schwerinae & 灌木 & 4 & 0.0111 & 0.0184 & 0.0078 & 0.0125 \\
\hline 小叶灰毛莸 & Caryopteris forrestii var. minor & 灌木 & 10 & 0.0143 & 0.0461 & 0.0318 & 0.0307 \\
\hline 皱叶腺花醉鱼草 & Buddleja agathosma var. glandulifera & 灌木 & 12 & 0.0154 & 0.0553 & 0.0221 & 0.0309 \\
\hline 西南蓄薇 & Rosa muirielae & 灌木 & 1 & 0.0159 & 0.0046 & 0.0097 & 0.0101 \\
\hline 架棚 & Ceratostigma & 灌木 & 2 & 0.0159 & 0.0092 & 0.0184 & 0.0145 \\
\hline 刺铁线莲 & Clematis delavayi var. spinescens & 灌木 & 3 & 0.0170 & 0.0138 & 0.0193 & 0.0167 \\
\hline
\end{tabular}




\begin{tabular}{|c|c|c|c|c|c|c|c|}
\hline 折叶白前 & Cynanchum forrestii var. conduplicatum & 灌木 & 32 & 0.0384 & 0.1475 & 0.1035 & 0.0965 \\
\hline 灰岩木蓝 & Indigofera calcicola & 灌木 & 22 & 0.0538 & 0.1014 & 0.1017 & 0.0856 \\
\hline 小鞍叶羊蹄甲 & Bauhinia brachycarpa var. microphylla & 灌木 & 25 & 0.2115 & 0.1152 & 0.1675 & 0.1647 \\
\hline 小叶荆 & Vitex microphylla & 灌木 & 34 & 0.2720 & 0.1567 & 0.1947 & 0.2078 \\
\hline 白刺花 & Sophora davidii & 灌木 & 34 & 0.3070 & 0.1567 & 0.2108 & 0.2248 \\
\hline
\end{tabular}

3 灰岩木蓝+胶粘香茶菜群系 Form. Indigofera calcicola+Rabdosia glutinosa

\begin{tabular}{|c|c|c|c|c|c|c|c|}
\hline $\begin{array}{c}\text { 中文名 } \\
\text { Chinese name }\end{array}$ & 拉丁名 Latin name & $\begin{array}{c}\text { 生长型 } \\
\text { Growth } \\
\text { form }\end{array}$ & $\begin{array}{l}\text { 出现样方 } \\
\text { 数 Number }\end{array}$ & $\begin{array}{c}\text { 相对盖度 } \\
\text { Relative } \\
\text { cover }\end{array}$ & $\begin{array}{c}\text { 相对频度 } \\
\text { Relative } \\
\text { frequency }\end{array}$ & $\begin{array}{c}\text { 相对多度 } \\
\text { Relative } \\
\text { abundance }\end{array}$ & $\begin{array}{c}\text { 重要值 } \\
\text { Important } \\
\text { value }\end{array}$ \\
\hline 三角金毛裸蕨 & Paragymnopteris sargentii & 草本 & 1 & 0.0001 & 0.0109 & 0.0003 & 0.0038 \\
\hline 猪毛菜 & Salsola collina & 草本 & 1 & 0.0001 & 0.0109 & 0.0003 & 0.0038 \\
\hline 巴塘报春 & Primula bathangensis & 草本 & 1 & 0.0011 & 0.0109 & 0.0017 & 0.0045 \\
\hline 针瓣景天 & Sedum obtusipetalum & 草本 & 1 & 0.0011 & 0.0109 & 0.0024 & 0.0048 \\
\hline 藜 & Chenopodium album & 草本 & 1 & 0.0011 & 0.0109 & 0.0024 & 0.0048 \\
\hline 马尔康䊁果芹 & Trachyspermum triradiatum & 草本 & 1 & 0.0011 & 0.0109 & 0.0017 & 0.0045 \\
\hline 岷江景天 & Sedum balfouri & 草本 & 1 & 0.0011 & 0.0109 & 0.0020 & 0.0047 \\
\hline 西南风铃草 & Campanula pallida & 草本 & 1 & 0.0011 & 0.0109 & 0.0014 & 0.0044 \\
\hline 腺毛唐松草 & Thalictrum foetidum & 草本 & 1 & 0.0011 & 0.0109 & 0.0017 & 0.0045 \\
\hline 小野养麦 & Fagopyrum leptopodum & 草本 & 1 & 0.0011 & 0.0109 & 0.0027 & 0.0049 \\
\hline 竹叶柴胡 & Bupleurum marginatum & 草本 & 1 & 0.0011 & 0.0109 & 0.0003 & 0.0041 \\
\hline 环根芹 & Cyclorhiza waltonii & 草本 & 2 & 0.0012 & 0.0217 & 0.0017 & 0.0082 \\
\hline 雪白粉背蕨 & Aleuritopteris niphobola & 草本 & 2 & 0.0012 & 0.0217 & 0.0027 & 0.0085 \\
\hline 角蒿 & Incarvillea sinensis & 草本 & 2 & 0.0021 & 0.0217 & 0.0020 & 0.0086 \\
\hline 纺锤根蝇子草 & Silene napuligera & 草本 & 3 & 0.0022 & 0.0326 & 0.0048 & 0.0132 \\
\hline 康定翠雀花 & Delphinium tatsienense & 草本 & 3 & 0.0022 & 0.0326 & 0.0020 & 0.0123 \\
\hline 石莲 & Sinocrassula indica & 草本 & 2 & 0.0022 & 0.0217 & 0.0037 & 0.0092 \\
\hline 黄细心 & Boerhavia diffusa & 草本 & 2 & 0.0043 & 0.0217 & 0.0031 & 0.0097 \\
\hline 白边卷柏 & Selaginella albocincta & 草本 & 2 & 0.0053 & 0.0217 & 0.0256 & 0.0175 \\
\hline 直茎点地梅 & Androsace erecta & 草本 & 4 & 0.0053 & 0.0435 & 0.0170 & 0.0219 \\
\hline 细裂叶松蒿 & Phtheirospermum tenuisectum & 草本 & 2 & 0.0063 & 0.0217 & 0.0102 & 0.0128 \\
\hline 西南菅草 & Themeda hookeri & 草本 & 3 & 0.0064 & 0.0326 & 0.0119 & 0.0170 \\
\hline 茅叶菍草 & Arthraxon prionodes & 草本 & 3 & 0.0074 & 0.0326 & 0.0075 & 0.0158 \\
\hline 真籽非 & Allium eusperma & 草本 & 3 & 0.0074 & 0.0326 & 0.0119 & 0.0173 \\
\hline 粗毛狗娃花 & Heteropappus altaicus var. hirsutus & 草本 & 8 & 0.0137 & 0.0869 & 0.0358 & 0.0455 \\
\hline 中华草沙蚕 & Tripogon chinensis & 草本 & 3 & 0.0212 & 0.0326 & 0.0613 & 0.0384 \\
\hline 细瘦卷柏 & Selaginella vardei & 草本 & 4 & 0.0316 & 0.0435 & 0.2003 & 0.0918 \\
\hline 禾本科一种 & Poaceae sp. & 草本 & 2 & 0.0496 & 0.0217 & 0.0467 & 0.0393 \\
\hline 白草 & Pennisetum flaccidum & 草本 & 2 & 0.0580 & 0.0217 & 0.0239 & 0.0345 \\
\hline 短穗冠芒草 & Enneapogon brachystachyus & 草本 & 9 & 0.1150 & 0.0978 & 0.1574 & 0.1234 \\
\hline 德钦画眉草 & Eragrostis deqinensis & 草本 & 10 & 0.1160 & 0.1086 & 0.1823 & 0.1357 \\
\hline 石胆草 & Corallodiscus flabellatus & 草本 & 2 & 0.2111 & 0.0217 & 0.0375 & 0.0901 \\
\hline 垫状卷柏 & Selaginella pulvinata & 草本 & 8 & 0.3206 & 0.0869 & 0.1336 & 0.1804 \\
\hline 对节刺 & Sagerretia pycnophylla & 灌木 & 1 & 0.0006 & 0.0099 & 0.0021 & 0.0042 \\
\hline 小鞍叶羊蹄甲 & Bauhinia brachycarpa var. microphylla & 灌木 & 1 & 0.0006 & 0.0099 & 0.0064 & 0.0056 \\
\hline 灰苍蒿 & Artemisia roxburghiana & 灌木 & 2 & 0.0007 & 0.0198 & 0.0064 & 0.0090 \\
\hline 黄花蒿 & Artemisia аппиа & 灌木 & 3 & 0.0019 & 0.0297 & 0.0128 & 0.0148 \\
\hline 小叶鹅线藤 & Cynanchum anthonyanum & 灌木 & 4 & 0.0020 & 0.0396 & 0.0192 & 0.0203 \\
\hline 折叶白前 & Cynanchum forrestii var. conduplicatum & 灌木 & 5 & 0.0026 & 0.0495 & 0.0192 & 0.0238 \\
\hline
\end{tabular}




\begin{tabular}{|c|c|c|c|c|c|c|c|}
\hline 白刺花 & Sophora davidii & 灌木 & 6 & 0.0044 & 0.0594 & 0.0235 & 0.0291 \\
\hline 雅致山蚂蝗 & Desmodium elegans & 灌木 & 2 & 0.0044 & 0.0198 & 0.0192 & 0.0145 \\
\hline 怒江蒿 & Artemisia nujianensis & 灌木 & 6 & 0.0057 & 0.0594 & 0.0684 & 0.0445 \\
\hline 云南土沉香 & Excoecaria acerifolia & 灌木 & 1 & 0.0064 & 0.0099 & 0.0043 & 0.0068 \\
\hline 小叶杭子梢 & Campylotropis wilsonii & 灌木 & 3 & 0.0083 & 0.0297 & 0.0385 & 0.0255 \\
\hline 小叶野丁香 & Leptodermis pilosa var. microphylla & 灌木 & 7 & 0.0134 & 0.0693 & 0.0449 & 0.0425 \\
\hline 小叶灰毛莸 & Caryopteris forrestii var. minor & 灌木 & 8 & 0.0337 & 0.0792 & 0.1303 & 0.0811 \\
\hline 架棚 & Ceratostigma minus & 灌木 & 7 & 0.0457 & 0.0693 & 0.2393 & 0.1181 \\
\hline 多花亚菊 & Ajania myriantha & 灌木 & 1 & 0.0635 & 0.0099 & 0.2778 & 0.1171 \\
\hline 头花香薷 & Elsholtzia capituligera & 灌木 & 2 & 0.0794 & 0.0198 & 0.1816 & 0.0936 \\
\hline 小叶荆 & Vitex microphylla & 灌木 & 8 & 0.0851 & 0.0792 & 0.1111 & 0.0918 \\
\hline 皱叶腺花醉鱼草 & Buddleja agathosma var. glandulifera & 灌木 & 8 & 0.1601 & 0.0792 & 0.1453 & 0.1282 \\
\hline 灰岩木蓝 & Indigofera calcicola & 灌木 & 13 & 0.2236 & 0.1287 & 0.8226 & 0.3916 \\
\hline 胶粘香茶菜 & Rabdosia glutinosa & 灌木 & 13 & 0.2579 & 0.1287 & 0.4444 & 0.2770 \\
\hline
\end{tabular}

4 小叶荆+小叶杭子梢群系 Form. Vitex microphylla +Campylotropis wilsonii

\begin{tabular}{|c|c|c|c|c|c|c|c|}
\hline $\begin{array}{c}\text { 中文名 } \\
\text { Chinese name }\end{array}$ & 拉丁名 Latin name & $\begin{array}{c}\text { 生长型 } \\
\text { Growth } \\
\text { form }\end{array}$ & $\begin{array}{c}\text { 出现样方 } \\
\text { 数 } \\
\text { Number }\end{array}$ & $\begin{array}{c}\text { 相对盖度 } \\
\text { Relative } \\
\text { cover }\end{array}$ & $\begin{array}{c}\text { 相对频度 } \\
\text { Relative } \\
\text { frequency }\end{array}$ & $\begin{array}{c}\text { 相对多度 } \\
\text { Relative } \\
\text { abundance }\end{array}$ & $\begin{array}{c}\text { 重要值 } \\
\text { Importan } \\
\text { value }\end{array}$ \\
\hline 岷江景天 & Sedum balfouri & 草本 & 1 & 0.0002 & 0.0238 & 0.0009 & 0.0083 \\
\hline 缺刻千里光 & Senecio scandens var. incisus & 草本 & 1 & 0.0002 & 0.0238 & 0.0009 & 0.0083 \\
\hline 矮龙葵 & Solanum nigrum var. humile & 草本 & 1 & 0.0022 & 0.0238 & 0.0037 & 0.0099 \\
\hline 川西獐牙菜 & Swertia mussotii & 草本 & 1 & 0.0022 & 0.0238 & 0.0028 & 0.0096 \\
\hline 多枝滇紫草 & Onosma multiramosum & 草本 & 1 & 0.0022 & 0.0238 & 0.0046 & 0.0102 \\
\hline 黄细心 & Boerhavia diffusa & 草本 & 1 & 0.0022 & 0.0238 & 0.0019 & 0.0093 \\
\hline 卷叶黄精 & Polygonatum cirrhifolium & 草本 & 1 & 0.0022 & 0.0238 & 0.0028 & 0.0096 \\
\hline 马尔康糙果芹 & Trachyspermum triradiatum & 草本 & 1 & 0.0022 & 0.0238 & 0.0028 & 0.0096 \\
\hline 二叶舌唇兰 & Platanthera chlorantha & 草本 & 1 & 0.0022 & 0.0238 & 0.0009 & 0.0090 \\
\hline 石莲 & Sinocrassula indica & 草本 & 1 & 0.0022 & 0.0238 & 0.0046 & 0.0102 \\
\hline 小野菾麦 & Fagopyrum leptopodum & 草本 & 1 & 0.0022 & 0.0238 & 0.0074 & 0.0111 \\
\hline 雪白粉背䕋 & Aleuritopteris niphobola & 草本 & 1 & 0.0022 & 0.0238 & 0.0056 & 0.0105 \\
\hline 真籽韭 & Allium eusperma & 草本 & 1 & 0.0022 & 0.0238 & 0.0056 & 0.0105 \\
\hline 从毛羊胡子草 & Eriophorum comosum & 草本 & 2 & 0.0044 & 0.0476 & 0.0056 & 0.0192 \\
\hline 多刺天门冬 & Asparagus myriacanthus & 草本 & 2 & 0.0044 & 0.0476 & 0.0028 & 0.0183 \\
\hline 直茎点地梅 & Androsace erecta & 草本 & 1 & 0.0065 & 0.0238 & 0.0260 & 0.0188 \\
\hline 白边卷柏 & Selaginella albocincta & 草本 & 2 & 0.0131 & 0.0476 & 0.0696 & 0.0434 \\
\hline 中华草沙蚕 & Tripogon chinensis & 草本 & 2 & 0.0131 & 0.0476 & 0.0678 & 0.0428 \\
\hline 扭黄茅 & Heteropogon contortus & 草本 & 1 & 0.0218 & 0.0238 & 0.0483 & 0.0313 \\
\hline 石胆草 & Corallodiscus flabellatus & 草本 & 1 & 0.0218 & 0.0238 & 0.0260 & 0.0239 \\
\hline 二歧马先蒿 & Pedicularis dichotoma & 草本 & 1 & 0.0327 & 0.0238 & 0.0139 & 0.0235 \\
\hline 狗尾草 & Setaria viridis & 草本 & 1 & 0.0327 & 0.0238 & 0.0650 & 0.0405 \\
\hline 西南菅草 & Themeda hookeri & 草本 & 1 & 0.0435 & 0.0238 & 0.0743 & 0.0472 \\
\hline 独尾草 & Eremurus chinensis & 草本 & 2 & 0.0566 & 0.0476 & 0.0576 & 0.0539 \\
\hline 芸香草 & Cymbopogon distans & 草本 & 4 & 0.1219 & 0.0952 & 0.1244 & 0.1139 \\
\hline 茅叶荩草 & Arthraxon prionodes & 草本 & 5 & 0.1831 & 0.1190 & 0.1532 & 0.1518 \\
\hline 垫状卷柏 & Selaginella pulvinata & 草本 & 4 & 0.4202 & 0.0952 & 0.2210 & 0.2455 \\
\hline 川滇野丁香 & Leptodermis pilosa var. pilosa & 灌木 & 1 & 0.0048 & 0.0370 & 0.0190 & 0.0203 \\
\hline
\end{tabular}




\begin{tabular}{llllllll}
\hline 刺铁线莲 & Clematis delavayi var. spinescens & 灌木 & 1 & 0.0048 & 0.0370 & 0.0095 & 0.0171 \\
胶粘香茶菜 & Rabdosia glutinosa & 灌木 & 1 & 0.0048 & 0.0370 & 0.0190 & 0.0203 \\
菊科一种 & Compositae sp. & 灌木 & 1 & 0.0048 & 0.0370 & 0.0095 & 0.0171 \\
沙针 & Osyris wightiana & 灌木 & 1 & 0.0048 & 0.0370 & 0.0190 & 0.0203 \\
陕西绣线菊 & Spiraea wilsonii & 灌木 & 1 & 0.0048 & 0.0370 & 0.0095 & 0.0171 \\
小鞍叶羊蹄甲 & Bauhinia brachycarpa var. microphylla & 灌木 & 1 & 0.0096 & 0.0370 & 0.0286 & 0.0251 \\
灰岩木蓝 & Indigofera calcicola & 灌木 & 1 & 0.0143 & 0.0370 & 0.0476 & 0.0330 \\
川康栒子 & Cotoneaster ambiguus & 灌木 & 2 & 0.0148 & 0.0741 & 0.0381 & 0.0423 \\
错枝榄仁 & Terminalia intricata & 灌木 & 2 & 0.0335 & 0.0741 & 0.0381 & 0.0485 \\
白刺花 & Sophora davidii & 灌木 & 2 & 0.0717 & 0.0741 & 0.1429 & 0.0962 \\
华西小石积 & Osteomeles schwerinae & 灌木 & 1 & 0.0717 & 0.0370 & 0.0857 & 0.0648 \\
革叶䒴花 & Wikstroemia scytophylla & 灌木 & 2 & 0.1196 & 0.0741 & 0.1429 & 0.1122 \\
小叶杭子梢 & Campylotropis wilsonii & 灌木 & 5 & 0.2343 & 0.1852 & 0.1714 & 0.1970 \\
小叶荆 & Vitex microphylla & 灌木 & 5 & 0.4017 & 0.1852 & 0.2190 & 0.2687 \\
\hline
\end{tabular}

5 小叶灰毛莸+胶粘香茶菜群系 Form. Caryopteris forrestii var. minor+Rabdosia glutinosa

\begin{tabular}{|c|c|c|c|c|c|c|c|}
\hline $\begin{array}{c}\text { 中文名 } \\
\text { Chinese name }\end{array}$ & 拉丁名 Latin name & $\begin{array}{c}\text { 生长型 } \\
\text { Growth } \\
\text { form }\end{array}$ & $\begin{array}{c}\text { 出现样方 } \\
\text { 数 } \\
\text { Number }\end{array}$ & $\begin{array}{c}\text { 相对盖度 } \\
\text { Relative } \\
\text { cover }\end{array}$ & $\begin{array}{c}\text { 相对频度 } \\
\text { Relative } \\
\text { frequency }\end{array}$ & $\begin{array}{c}\text { 相对多度 } \\
\text { Relative } \\
\text { abundance }\end{array}$ & $\begin{array}{c}\text { 重要值 } \\
\text { Important } \\
\text { value }\end{array}$ \\
\hline 康定翠雀花 & Delphinium tatsienense & 草本 & 1 & 0.0003 & 0.0476 & 0.0010 & 0.0163 \\
\hline 滇非 & Allium mairei & 草本 & 2 & 0.0057 & 0.0952 & 0.0207 & 0.0405 \\
\hline 卷叶黄精 & Polygonatum cirrhifolium & 草本 & 1 & 0.0057 & 0.0476 & 0.0052 & 0.0195 \\
\hline 直茎点地梅 & Androsace erecta & 草本 & 1 & 0.0057 & 0.0476 & 0.0207 & 0.0247 \\
\hline 岷江景天 & Sedum balfouri & 草本 & 2 & 0.0085 & 0.0952 & 0.0207 & 0.0415 \\
\hline 真籽非 & Allium eusperma & 草本 & 2 & 0.0199 & 0.0952 & 0.0363 & 0.0505 \\
\hline 独尾草 & Eremurus chinensis & 草本 & 3 & 0.0312 & 0.1429 & 0.0591 & 0.0777 \\
\hline 粗毛狗娃花 & Heteropappus altaicus var. hirsutus & 草本 & 3 & 0.0852 & 0.1429 & 0.0487 & 0.0923 \\
\hline 德饮画眉草 & Eragrostis deqinensis & 草本 & 2 & 0.0568 & 0.0952 & 0.1244 & 0.0921 \\
\hline 白草 & Pennisetum flaccidum & 草本 & 2 & 0.0852 & 0.0952 & 0.0518 & 0.0774 \\
\hline 茅叶荩草 & Arthraxon prionodes & 草本 & 1 & 0.2698 & 0.0476 & 0.2798 & 0.1991 \\
\hline 细柄草 & Capillipedium parviflorum & 草本 & 1 & 0.4260 & 0.0476 & 0.3316 & 0.2684 \\
\hline 白刺花 & Sophora davidii & 灌木 & 1 & 0.0018 & 0.0455 & 0.0067 & 0.0180 \\
\hline 峨嵋蓄薇 & Rosa omeiensis & 灌木 & 1 & 0.0018 & 0.0455 & 0.0033 & 0.0169 \\
\hline 小叶野丁香 & Leptodermis pilosa var. microphylla & 灌木 & 1 & 0.0018 & 0.0455 & 0.0033 & 0.0169 \\
\hline 怒江蒿 & Artemisia nujianensis & 灌木 & 1 & 0.0037 & 0.0455 & 0.0067 & 0.0186 \\
\hline 小叶栒子 & Cotoneaster microphyllus & 灌木 & 1 & 0.0037 & 0.0455 & 0.0234 & 0.0242 \\
\hline 灰苞蒿 & Artemisia roxburghiana & 灌木 & 3 & 0.0128 & 0.1364 & 0.0268 & 0.0586 \\
\hline 小鞍叶羊蹄甲 & Bauhinia brachycarpa var. microphylla & 灌木 & 1 & 0.0366 & 0.0455 & 0.0134 & 0.0318 \\
\hline 小叶鹅线藤 & Cynanchum anthonyanum & 灌木 & 2 & 0.0457 & 0.0909 & 0.0669 & 0.0678 \\
\hline 束花铁马鞭 & Lespedeza fasciculifora & 灌木 & 1 & 0.0731 & 0.0455 & 0.1003 & 0.0730 \\
\hline 革叶尧花 & Wikstroemia scytophylla & 灌木 & 1 & 0.0731 & 0.0455 & 0.1070 & 0.0752 \\
\hline 灰岩木蓝 & Indigofera calcicola & 灌木 & 3 & 0.0859 & 0.1364 & 0.1538 & 0.1254 \\
\hline 胶粘香茶菜 & Rabdosia glutinosa & 灌木 & 3 & 0.2834 & 0.1364 & 0.1940 & 0.2046 \\
\hline 小叶灰毛莸 & Caryopteris forrestii var. minor & 灌木 & 3 & 0.3766 & 0.1364 & 0.2943 & 0.2691 \\
\hline
\end{tabular}




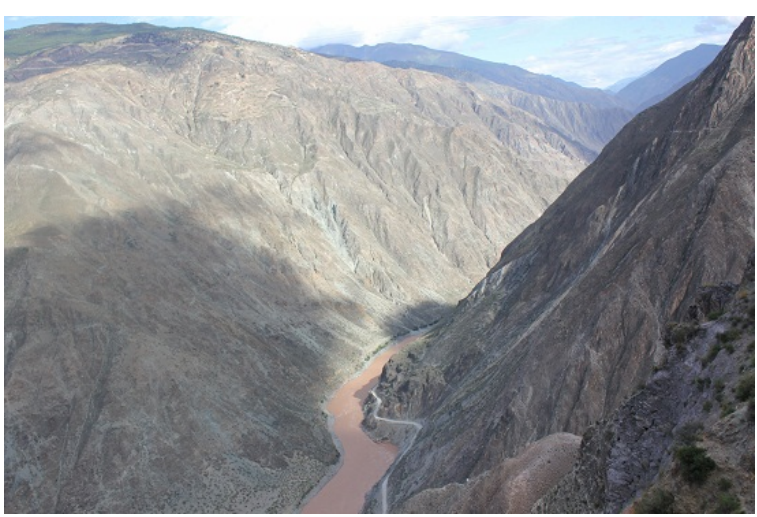

金沙江上游"V"型河谷 Dry valleys of the upstream of Jinsha River

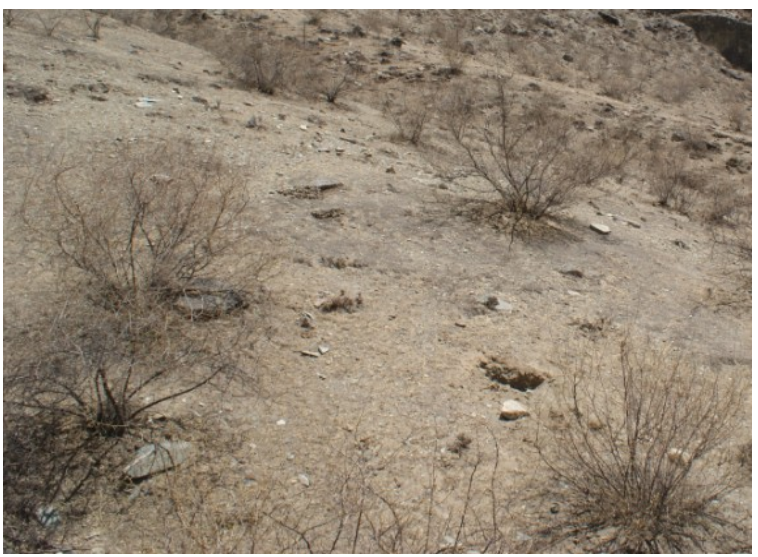

白刺花+小叶荆群系 Form. Sophora davidii + Vitex microphylla

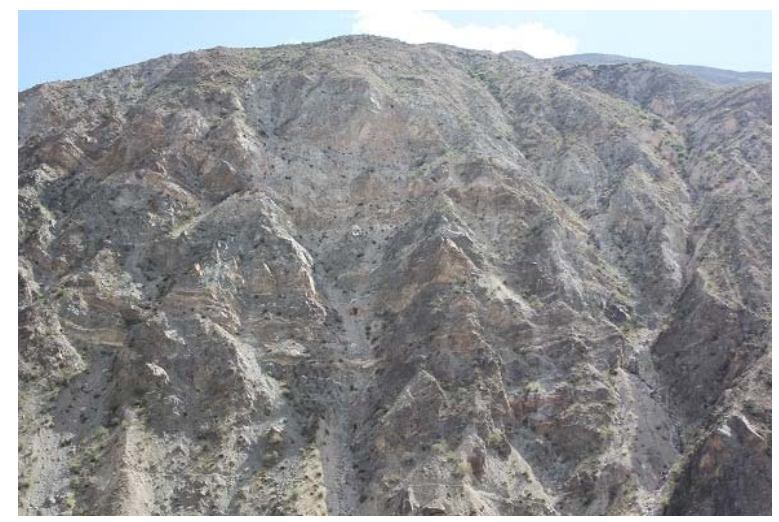

金沙江上游干旱河谷荒漠植被 Desert vegetation in dry valleys

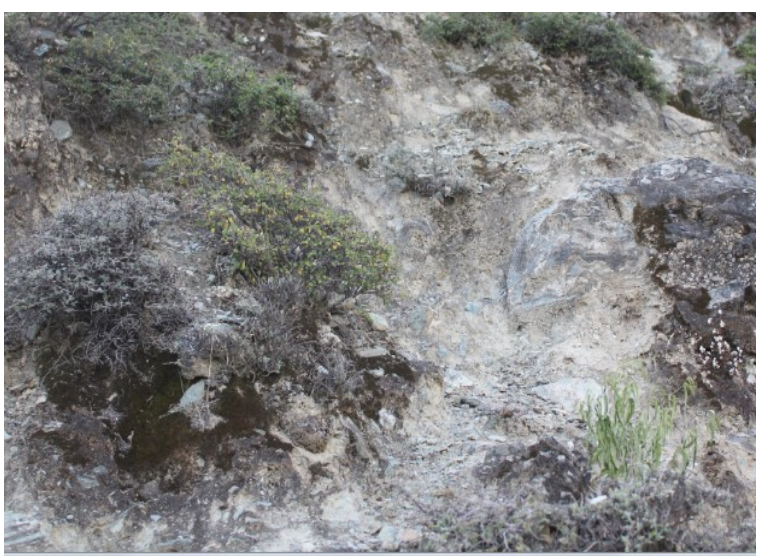

灰岩木蓝+胶粘香茶菜群系 Form. Indigofera calcicola+Rabdosia glutinosa

附录3 金沙江上游干旱河谷区部分生境及群系照片

Appendix 3 The photos of habitat and plant formations in dry valleys of the upstream of Jinsha River 